\title{
Taiwan's Challenges in the Changing Landscape of Regional Security and Economy in the Asia-Pacific Region after the Cold War
}

\begin{abstract}
After the Cold War, international politics and economy of the Asia-Pacific region has changed tremendously. Regional economic integration accelerates up with the rapid increase of bilateral and multilateral free trade agreements between regional countries, whereas regional security is continually confronted with conflict flashpoints, including regional maritime sovereignty disputes. This article provides the recent development of regional economy and security with emphasis on maritime disputes in East China Sea and South China Sea and Trans-Pacific Partnership (TPP) and Regional Comprehensive Economic Partnership (RCEP) and discusses the possible challenges to Taiwan in these issues.
\end{abstract}

Keywords: TPP, RCEP, East China Sea, South China Sea, Taiwan, the Asia-Pacific region

\section{Preface}

Over two decades, the dynamics of international political and economic interaction in the Asia-Pacific region underwent a huge change. Economic integration in the region has increased at an unprecedented rate both in depth and width, especially the recent development of the Trans-Pacific Partnership (TPP) and the Regional Comprehensive Economic Partnership (RCEP). In November 2014, China attempted to reinvigorate the process of the Free Trade Area of the Asia-Pacific (FTAAP) by proposing the Beijing Roadmap in the Asia-Pacific Economic Cooperation (APEC). In contrast to the flourishing development of regional economic cooperation and integration, regional security is still at high risk of conflict, such as the territorial disputes over the East China Sea and the South China Sea. The increasing competition between the US and China over the arrangement of regional security and economic 
order is accelerating regional economic transformations and heating the flashpoints. Undoubtedly, Taiwan as an Asia-Pacific country cannot do anything but cautiously confront those regional economic and security developments. However, the cross-strait relation is a unique and formidable hurdle to face when Taiwan wants to effectively participate in those regional developments to maintain its national interests. The former Ma Yin-jeou government (2008-2016) of Taiwan attempted to tackle this obstacle through closer political and economic relations with China. However, the Ma administration's China policy incurred considerable doubts in Taiwan's domestic society, which triggered the Sunflower Movement that generated a great impact on Taiwan's domestic politics. As a result, the negotiations of economic agreements between Taiwan and China under the Economic Cooperation Framework Agreement (ECFA) were then slowed down. The cross-strait relations are further cooled down after Taiwan's Democratic Progress Party took over the office from the Chinese Nationalist Party (Kuomintang) in May 2016. The changing dynamics of regional relations, cross-strait relations, and domestic political and economic transformation brings the new government in Taiwan more pressing challenges in the future. This article is to illustrate the current development of the Asia-Pacific region's security and economy, focusing on the East China Sea and the South China Sea issues and the TPP and the RCEP. It is followed with discussions on the challenges for Taiwan amid such tremendous regional changes and how to deal with them.

\section{The Current Security and Economic Situation in the Asia-Pacific Region}

\section{Regional Security: Territorial Disputes of the East China Sea and the South China Sea}

The East Asia regional seas issue concerns not only the maintenance of the sovereignty of the related countries, but it also involves the division of the Exclusive Economic Zone (EEZ) and the distribution of the marine resource development. Diaoyutai (in Japan: Senkaku islands) is center of the East China Sea disputes in which Taiwan, Japan, and China involve. In 1971, the United States and Japan reached the agreement to return the Ryukyu Islands to the latter, which entered into force in 1972. However, the agreement only transferred the administrative authority, rather than the full sovereignty, of Diaoyutai to Japan, leaving controversy over the sovereignty of the islands among Taiwan, Japan and China more than 40 years. At that time, China and Taiwan respectively made solemn protests about the disposal 
of the United States mainly through official, diplomatic or civil movements. China addressed the Diaoyutai issue by announcing that "we should set aside sovereignty disputes and jointly exploit natural resources" instead of launching a fierce debate or battle. That was because of considering the development of the bilateral relations after the establishment of formal diplomatic relations with Japan in 1972. This declaration was mentioned again when the Treaty of Peace and Friendship between Japan and China in 1978. However, after the United Nations. Convention on the Law of the Sea (UNCLOS) in 1982, China and Japan asserted different principles of sea boundary delimitation to claim its EEZ in the East China Sea [Wang Gaocheng, 2012, pp. 61-63 $]^{1}$. Such diverge renders Diaoyutai which is geographically located in the middle line of the East China Sea area between Japan and China a highly crucial place concerning how the boundary of EEZ to be delimited and in turn national sovereignty maintenance. As a result, Diayutai became the focus of the East China Sea disputes. After the Cold War, China has every now and then put pressure on Japan because of the Japanese right-wingers landing on the islands and attempting to claim their sovereignty or because of the arrest of the Chinese fishermen entering the Diaoyutai territorial sea for fishing by the Japanese government. Although those incidents to some extent were escalated to interstate disputes, after the incident had calmed down the two countries returned to the policy of putting the maritime disputes aside and promoting joint marine development. However, both Japan and China recently are incrementally taking tougher actions to maintain its sovereignty, which makes the status quo deteriorating. In September 2010, a Chinese fishing boat and a Japanese Coast Guard vessel collided in the Diaoyutai waters, causing a diplomatic conflict and postponed negotiations on the agreement of joint development in the East China Sea [Lin Zhengyi, Chen Hongjun, 2014, pp. 38-39; Diaoyutai Collision..., 2010]. Since then, China began to send Fisheries Administration Ships to carry out regular maritime surveillance around the Diaoyutai waters, showing intensifying intervention of China on the issue of the East China Sea [China Sent Boats..., 2010; Cai Zengiia, 2012, pp. 43-44]. Faced with changes of China’s policy behavior, Japan also turned to take more active policy on Diaoyutai. In April 2012, then governor of Tokyo, Shintaro Ishihara, put forward to purchase the ownership of Diaoyutai on behalf of Tokyo with organizing the fundraising campaign all over the country. This national campaign forced then Joshihiko Noda's government to make a decision in September 2012 to buy the ownership of Diaoyutai with the government's

1 China advocates the principle of natural extension of the continental shelf, and therefore the dividing line of access onexclusive economic sea zone between China and Japan is the Ryukyu Trench; while Japan advocates the principle of the middle line division, therefore the middle line of coast distance between the two countries is the basic point for demarcation. 
funds, which in fact essentially nationalized Diaoyutai. Japan's move of Diaoyutai nationalization triggered a backlash from China because it was considered a fundamental change to the status quo in the East China Sea. Consequently, China not only immediately launched diplomatic negotiations with Japan but also took a series of counter-measures to maintain sovereignty over Diaoyutai, including the publication of Diaoyutai's territorial baseline, submitting the baseline coordination table and a marine chart to the United Nations Secretary-General, continuing maritime surveillance around the islands and holding military exercise in the East China Sea [Wang Gaocheng, 2012, pp. 62-65; Lin Zhengyi, Chen Hongjun, 2014, p. 39]. In November 2013, China announced the East China Sea Air Defense Identification Zone (ADIZ) intending to further legitimize its sovereignty over Diaoyutai. Recently, China has built a military base with monitoring capability and a helipad in the Nanji islands which is 300 kilometers northwest of the Diaoyutai islands [James' Defense..., 2015]. In addition to regular air and maritime surveillances and military activities, China also increased oil exploration activity in the East China Sea [NIKKEI Zhongwen, 2015, BBC Zhongwen, 2015]. In 2015, in order to response to the changing security environment in East Asia (also as a counteraction to China's recent assertive actions), the Abe Shinzo's government passed a series of security bills, coordinated with the new Guideline for US-Japan Defense Cooperation, allowing Japan's Self-Defence Forces (SDF) with the permission of the Diet to help the US and its allies even if Japan is not under attack itself. The interactions between the two countries over the Diaoyutai issue continually make their security relations in a high tension, but without breakdown.

Similarly, the South China Sea also undergoes disputes as same as that occurred in the East China Sea, but it is in more complicate situation because of more territorial claimants involved, including Brunei, China, Indonesia, Malaysia, the Philippines, Taiwan, and Vietnam. Conflicts between Vietnam and China and between the Philippines and China are most serious. In 1974, Vietnam were in militarized conflict with China over over the Paracel Islands which is under China's control at the end. It is followed by China's control over the Johnson South Reef as a result of sea battle between the two countries in 1988. Although China proposed in 1990 that the related disputants should conduct joint development in the disputed waters and normalized the relations with Vietnam in 1991, it later announced“.

The Law of the People's Republic of China on the Territorial Sea and the Contiguous Zone" in February 1992, indicating that the Pratas (Dongsha) Islands, the Paracel (Xisha) Islands, the Zhongsha Islands and the Spratly (Nansha) Islands in the South China Sea are parts of the Chinese territory. In May 1992 China planned to explore oil and gas around the Spratly Islands, which caused Vietnam's protests. In July 1992, 
the Association of Southeast Asian Nations (ASEAN) issued "the ASEAN Declaration on the South China Sea" and called for "the code of international conduct over the South China Sea" to peacefully settle the disputes. China however continued expanding effective control over its claimed territories in the South China Sea. For example, China occupied the Mischief Reef in 1995 and announced the Paracel Islands as tourism areas in 1998 and built up a satellite-receiving station in the Paracel Islands. All of these activities again sparked strong protests on the part of the Philippines and Vietnam [Lin Zhengyi, 2012, pp. 91-94]. After a series of protests and negotiation, China and the ASEAN worked out in November 2002 the "Declaration on the Conduct of Parties in the South China Sea" (the DOC), hoping that the related parties in disputes could mitigate disagreement through dialogue, jointly maintain peace and stability in the region, and at the end establish a binding "Code of Conduct of Parties in the South China Sea" (the COC) to regulate the activities in the South China Sea. Although the ASEAN member states and China intended to construct confidence-building measures via the ASEAN-China Joint Working Group on the Implementation of the DOC, the strong incentive of sovereignty protection of territorial claimants weakened the efforts of the working group meetings [Lin Zhengyi, 2012, pp. 104-105; Li Qiongli, 2012, pp. 121-123]2. Especially in recent years, the frequency and intensity of sovereignty protection activities of the disputants have increased, for example, China sent the largest fishery administration ship to patrol the Paracel Islands in 2009, and in the same year the Philippines claimed parts of the Spratly islands and the Scarborough Shoal as the Philippines' territory, while Malaysia and Vietnam submitted their continental shelf delimitations to the Commission on the Limits of the Continental Shelf (CLCS). In order to counter the Philippines, Malaysia and Vietnam, China put forward a notification to express its objection and set up the Department of Boundary and Ocean Affairs under the Ministry of Foreign Affairs. Through the Islands Protection Act it had strengthened its legitimacy of controlling the South China Sea [China's Sending Fishery..., 2009; Lin Zhengyi, 2012, pp. 96-97; Wang Guanxiong, 2012, pp. 258-261]³. In May 2011, Chinese marine surveillance ship cut the working cables of the PetroVietnam's exploration ship off the coast of Vietnam, resulting in mutual accusations, and in the same year, Vietnam took a military exercise as a response [Vietnam Protested Again..., 2011].

2 Declaration on the Conduct of Parties in the South China Sea - DOC is a political document, not-binding treaty, but can be seen as conflict prevention measures.

3 Under the "United Nations Convention on the Law of the Sea", the coastal states shall report their continental shelf boundaries before May 13, 2009 to establish order of the sea world. The claimant countries of the South China Sea islands and reefs include: China, Vietnam and the Philippines. Malaysia and other countries also claimed before the expiry date. 
In April 2012, the Philippines' warships tried to arrest and detain Chinese fishermen and their fishing boats around the Scarborough Shoal but they were prevented by the Chinese maritime surveillance ships, also resulting in conflicts between the Philippines and China which lasted over a month. After the incident, the Philippines proposed to submit the Scarbough Shoal disputes to the International Tribunal for the Law of the Sea, but China objected. In September of the same year, the Philippines president Benigno Simeon Aquino III promulgated the Execution Order to name a part of the Philippines west coast of the South China Sea "the West Philippines Sea" and submitted the territorial map with the revision to the United Nations [The Philippines Named..., 2012] $]^{4}$. While the Scarborough Shoal is in effect under China's control, Manila filed the arbitration application to the Permanent Court of Arbitration on 22 January 2013 and then submitted the memorial on 30 March 2014, which sparked legal as well as political battles between Manila and Beijing [CNA News, 2013; BBC Zhongwen, 2014]. At the beginning of May 2014, the China National Offshore Oil Corporation moved its rig "HD981" to the sea area which is only 120 miles away from Vietnam's coast, planning the exploration of oil for three months. The move of "HD981" into Vietnam's claimed EEZ and continental shelf was regarded illegal and brought about not only standoff and collision of the two countries but also violent anti-Chinese protests in Vietnam. Meanwhile, China in the past few years has quietly extended land reclamation in massive scale and constructed massive basic infrastructure and military facilities on the occupied islands and reefs. For instance, an airstrip was built on Fiery Cross Reef and missiles and fighter airplanes have been deployed on Woody Island [BBC Zhongwen, 2016; CNA News, 2016a; CNA News, 2016b]. These recent events showed that tensions of the South China Sea is incrementally rising. From the strategic point of view, China actively legalizes its marine administration and expands effective control of the occupied islands in order to its sovereignty claim over the South China Sea. On the other hand, China continues bilateral negotiation with the claimants as well as other regional countries in order to prevent a united front formed in ASEAN and East Asia and then weaken internationalization of the South Sea issue. On the contrary, internationalizing the South China Sea issue through an international legal system and multilateral channels is mainly intended by Southeast Asian claimants. Cooperation with the United States and Japan is also taken to counterbalance China's assertiveness in the sea. For example, the Philippines was supported by the U.S. on the South China Sea Arbitration. Meanwhile, it is also intensifying military cooperation with Japan, represented in recent participation of

4 The West Philippines Sea delineated by the Philippines include: Luzon Sea, the waters around, in which the Pagasa Island is located and the Scarborough Shoal Island waters. 
Japanese SDF in the Balikatan military exercise in Subic Bay in April 2016. However, although the tension is increasing, it is avoided to escalate to the war.

Concerning the U.S. policy to the South China Sea, its policy stance is gradually moving from indirect involvement to direct intervention. As to the Diaoyutai issue, the United States is against the change of the status quo by either China or Japan. Japan's nationalization of the islands and China's setting of the ADIZ in the East China have crossed the line of the United States. In the previous conflicts between China and Japan, the United States keeps recognizing Japan's administrative authority of Diaoyutai and reiterates that the islands is covered by the Treaty of Mutual Cooperation and Security between the US and Japan, while it also explicitly states that its security commitment to the regional allies should not be regarded as a support to their specific policies which may erode the US regional interests [Secretary Panetta..., 2012]. After China's announcement of the ADIZ, the United States also immediately sent unarmed B-52 bombers to fly over the identification zone as a response [British Media..., 2013]. These actions of the US were taken to constrain behaviors of both China and Japan on the Diaoyutai. However, China's increasingly assertive activities has impelled the US to more explicitly support Japan.

On the South China Sea issue, the US also heightens its counterbalance to China. Although the US does not take a certain stance to any specific country's sovereignty claim on the islands and reefs in the South China Sea, it on the one hand continuously expresses serious concerns to the freedom of navigation and trade and encourages the claimants to peacefully resolve maritime disputes through multilateral diplomatic consultations and negotiations at many regional multilateral institutions, such as the ASEAN-US summit, the ASEAN Regional Forum, and the East Asia Summit. On the other hand, the US is actively strengthening and modernizing the regional security alliance system [The US Secretary..., 2010]. For example, the US in the 2015 East Asia summit successfully put the South China Sea issue in the summit agenda under China's considerable resistance and listed the issue in top priority. In addition to diplomatic manners, the US also heightened its military counterbalance against China by operating the maintenance of navigation freedom in South China Sea with regular maritime and aerial surveillances and actively integrating and strengthening their military cooperation with the first island chain countries (Japan, the Philippines, and Australia) and non-traditional allies, such as Vietnam [The US Military Urged..., 2014; China Claimed..., 2015; On Check..., 2015; American Defense..., 2015]5.

5 China actively reclaim sea at Johnson South Reef, Cuarteron Reef, Gaven Southern Reef and Fiery Cross Reef in the South China Sea, in which Fiery Cross Reef is the largest reef and there are also garrison, docks, anti-aircraft guns and communiction equipment. See Hardy and O'Connor [2014]. 


\section{Regional Economic Integration: The TPP and the RCEP}

At the end of the Cold War, the Asia-Pacific regional economic integration is promptly accelerated. According to the statistics of the Asian Development Bank (the ADB) in Figure 1, there have been 144 free trade agreements signed, 69 in negotiation and 65 proposed $^{6}$. The figure shows that the number of Free Trade Agreements (bilateral and multilateral) largely increases after 2000. Of those developing FTAs, TPP and RCEP are the center of the new wave of economic integration in the Asia-Pacific region.

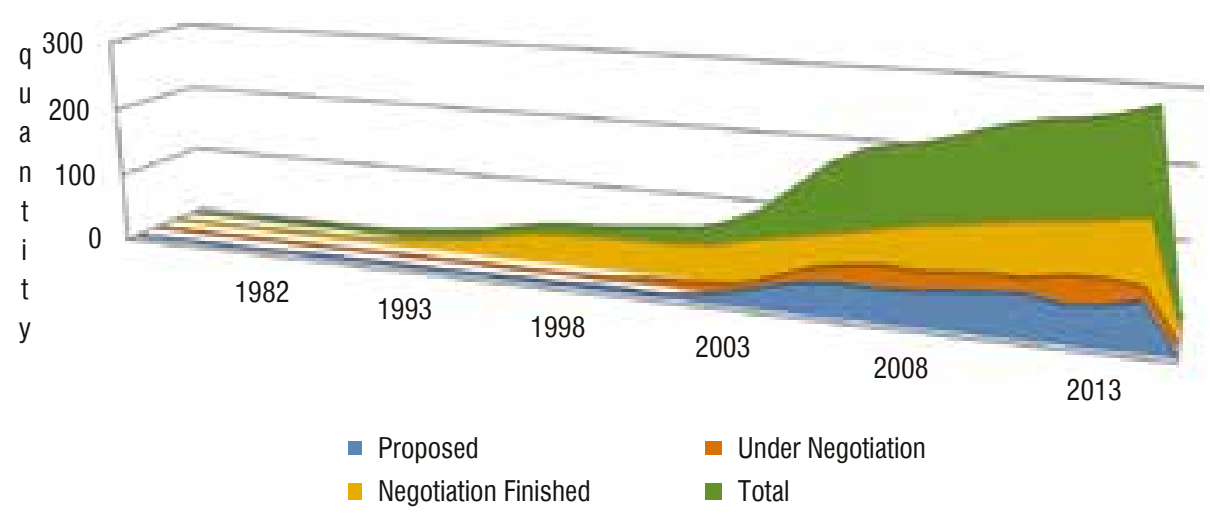

Figure 1. The Trend of Regional Economic Integration Agreements (1975-2014)

Source: Asian Regional Integration Center, Table 1. FTA by Status (cumulative), Asian Development Bank, http://aric.adb.org/fta (28.01.2015).

APEC, a low-binding regional forum, was expected by the US as the primary impetus for institutionalizing regional economic integration, while it however failed to achieve the goal because of enormous political and economic differences between the member states and some member states' concerns of the US dominance in the regional integration process. Since the US worry of being excluded from rising East

6 The ADB calls FTA as regional economic integration agreement. Since a regional economic integration agreement includes at least two economic entities, there will be a double count of a country's exact number of FTAs when using the ADB data. As a result, total number of country-wise regional economic integration agreements will be more than that of region-wise economic integration agreements in Asia. The forming stage of FTV is: I. In Plan: the parties considering of regional economic integration agreement establish a joint research group or a joint working group to implement feasibility assessment; II. In Negotiation: the parties is negotiating over or finalizing the contents of a preliminary framework agreement as a base of future negotiation, or the parties is directly in negotiation without a framework agreement; III. Negotiation in Completion: the agreement is signed by the parties and approved by their own domestic legislative or administrative authority or enters into force. 
Asian regionalism that designates regional states a driving seat, it has tried to advance the FTAAP in 2006 but made no meaningful progress at the end. Against this background, the US turned to the TPP in September 2008, looking forward to giving new impetus to free trade liberalization in the APEC as well as maintaining the leading position in the regional integration process ${ }^{7}$. After the US joined the TPP negotiation and then became the dominant participant, the membership coverage of the TPP quickly expanded. Except for the original member states and the United States, Australia, Peru, Vietnam, Malaysia, Mexico, Canada and Japan joined in one after another. Currently, the total GDP of the TPP members as of 2013 occupied $38 \%$ of the global GDP, which speaks itself as a considerable force in the world politics and economy ${ }^{8}$. The TPP is a high-quality free trade agreement which involves a wide range of trading issues, requires the entire open of domestic market, and integrates the regional supply chain. Therefore, the participants have to overhaul its own domestic economic and legal systems to accomplish the TPP requirements, which may render greater political and economic confrontation at home. In other words, the difficulty to finalize the TPP will be much higher [Ye Changcheng, 2014, pp. 32-35]. However, under the forceful conduct of the US, all TPP participants has reached the final terms of the agreement and signed in April 2016 after 20 rounds of negotiations in last five years.

When the United States had been actively promoting the TPP, ASEAN also passed the "ASEAN Framework for Regional Comprehensive Economic Partnership" during the nineteenth ASEAN leaders' meeting in 2011 and then officially launched the RCEP negotiations in 2013. ASEAN initiated the RCEP because the levels of liberalization of five ASEAN + 1s are incompatible to each other and the ASEAN + 3 and the ASEAN +6 as complementary to the ASEAN +1 s did not effectively push forward the regional economic integration as expected, and because the formation of the TPP and the China-Japan-South Korea Free Trade Agreement are posing challenge to the ASEAN's driving seat in the regional integration. At the present stage, the RCEP has 16 member states, including the all ASEAN member states, Australia, China, India, Japan, Korea, and New Zealand. Their goal is to integrate the existing commitments

7 The TPP is originated from the "Trans-Pacific Strategic Economic Partnership Agreement, TPSEP" by New Zealand, Singapore, Chile and Brunei in 2005, which is a regional trade agreement connecting Asia, the Pacific and Latin America. The idea of TPP was initiated in the background that during the 1997 Asian financial crisis the US rather intended to push forward the liberalization policy than help the affected Asian countries to get out from the crisis in the region, sparking the discontent of Japan, China, Korea and the ASEAN countries who later decided to initiate "ASEAN Plus Three, APT" to cope with the new regional economic shock.

8 The global share of GDP in the TPP and the following RCEP is counted on the basis of the statistical data of the IMF in 2013. 
and resources, based on the five ASEAN $+1 \mathrm{~s}$, in order to achieve a higher degree of regional trade liberalization and keep ASEAN as the center of the process. The design of the RCEP is to enlarge market openness without contravening existing bilateral or multilateral FTAs. Because of the differences in the levels of economic development between the participants, the RCEP will adopt progressive negotiations, providing flexible measures for the relatively under-developed countries, such as a longer adjustment period, etc. In other words, the RCEP's entire openness will be lower than that of the TPP. However, the RCEP is a free trade area with a share of nearly $29 \%$ of global GDP as of 2013, more than 3 billion population, and rich natural resources, which renders the RECP a promising market in the world. Moreover, the establishment of the RCEP will exert a profound influence on economic activities of domestic and foreign enterprises within and without the RCEP as a result of that the industrial connections between ASEAN and Japan, Korea and China is getting than ever.

\section{Challenges to Taiwan}

Amid the changing landscape regional security and economy in the Asia-Pacific region, Taiwan has to cautiously cope with impacts of the competition between the United States and China. Undoubtedly, China's rise is the primary force transforming international political structure in East Asia after the Cold War. After the three generations of development led by Deng Xiaoping, Jiang Zemin and Hu Jintao, China has become the world's largest economy and its military power has risen onto the top rank $^{9}$. On this substantial base, China under Xi Jinping since November 2012 began to incrementally demonstrate more ambitious and assertive policy stance to maintain national interests in regional security and economic affairs. In order to balance the US comprehensive return to Asia, China not only joined ASEAN to promote the RCEP but also started several grand economic initiatives, including "one belt (Silk Road Economic Belt) and one road (Maritime Silk Road of the $21^{\text {st }}$ century) $)^{10}$, "Beijing roadmap" for the FTAAP [APEC, 2014], and the "Asia Infrastructure Investment and

9 The IMF in the "World Economic Outlook" issued in October 2014, noted that China will surpass the United States as the world's largest economic entity with 17,600,000,000,000 USD to 17,400,000,000,000, when calculated on the basis of Purchasing Power Parity.

${ }^{10}$ In September 2013, when Xi Jinping was in four Central Asia countries (Turkmenistan, Kazakhstan, Uzbekistan, Kyrgyzstan) for a state visit, he proposed a concept in a speech in Kazakhstan that China would cooperate with the Central Asian countries in the construction and development of the "Silk Road Economic Belt" (also called "New Silk Road" with a new model). When he visited Indonesia in the same year, he put forward that China would strengthen maritime cooperation with the ASEAN countries, by creating the " $21^{\text {st }}$ Century Maritime Silk Road" (also called the "New Maritime Silk Road"). After that, the initiative of "one belt one road" was formally brought into future key tasks of the Chinese government 
Development Bank" which is designed to support the "one belt, one road" [China Pushes..., 2014]. These initiatives, if successfully implemented, would undoubtedly enhance the autonomy and domination of China in the regional affairs.

China's ambition to lead regional affairs motivated the U.S. to comprehensively reconsider and reevaluate the role of Asia in its global strategic layout, represented in proposed strategic concepts of "returning to Asia", "Pivot to Asia" and "Rebalancing" in the recent years. In addition to the existing bilateral alliance framework, the U.S. also copes with regional security issues by encouraging and involving in the development of regional multilateral security mechanisms, such as the ASEAN Regional Forum. Meanwhile, the TPP is regarded as an important tool for the U.S. to deepen economic with regional allies so as to consolidate its leadership in the region. How to maintain autonomy and avoid marginalization in such dynamics of hegemonic competition becomes a serious challenge to Taiwan.

On the East China Sea and South China Sea territorial issues, Taiwan is as anxious as other disputants, trying to protect its sovereignty and ensure the freedom of navigation and the right of using marine resources. But China's rising political and economic role critically compresses Taiwan's diplomatic space to address maritime issues. The One-China Policy significantly reframes the related parties from further cooperation with Taiwan in the East China Sea and the South China Sea. On the one hand, these related parties don't want to deteriorate the relationship with China because cooperation with Taiwan on sovereignty-related maritime issues implies recognizing Taiwan as independent sovereignty state, which is against One-China Policy. On the other hand, the related parties worry of whether Taiwan can firmly stand its feet in face of China when China now has certain economic and political influence on Taiwan due to the latter's highly economic dependence to China's market. Therefore, cooperating with China on regional maritime issues may not only risk blurring Taiwan's sovereignty status but also decrease the possibility to cooperate with other related parties.

To address the Diaoyutai issue, the former Ma Ying-jeou government of Taiwan proposed "the East China Sea Peace initiative" (the ECSPI) in 2012, expecting to resolve the Diaoyutai disputes by establishing the East China Sea Code of Conduct ${ }^{11}$. On the South China Sea issue, although Taiwan is the key claimant and supports the establishment of the COC, it is still excluded from dialogues and consultations over the COC because of China. In this context, Taiwan is rather a passive claimant in the

in the "Third Plenary Session of the $18^{\text {th }}$ Central Committee of the Chinese Communist Party" and the "The Central Economic Work Conference in 2013".

${ }^{11}$ For the content of ECSPI, please see The R.O.C. Ministry of Foreign Affairs [2012]. 
South China Sea. However, on 26 May 2012, the Ma administration government proposed "the South China Sea Peace initiative" (the SCSPI), emulating the ECSPI, in order to prevent from being marginalized on the South China Sea issue ${ }^{12}$. From strategic point of view, the maritime peace initiatives by the Ma administration are intended to pave a way for Taiwan to more effectively participate in regional security cooperation. Although the US welcomes the two peace initiatives [Kerry: The East China..., 2015; The United States Appreciated..., 2015], it supports Manila's stance in the South China Sea arbitration case, which means that it is against to Taiwan's U-Shape Line in delimitation of South China Sea territory because the U-Shape Line overlaps the China's Nine-Dash line which is opposed in the arbitration case [Lin, Cheng-Yi, 2016, pp. 39-47]. On 12 July 2016, the international tribunal of arbitration rendered its award for the South China Sea case, refuting the China's Nine-Dash Line and indicating Taiwan's Itu Aba Island as a 'rock' that do not generate an exclusive economic zone or continental shelf. This result makes a challenging condition to the new Tsai Ing-wen government of Taiwan in dealing with maritime issues. In this regard, Taiwan has to more explicitly show international society that China's assertive behaviors in the South China Sea is not in interest of Taiwan in order to convince the other related parties to cooperate with Taiwan in the future. Furthermore, the result of the South China Sea Arbitration will possibly affect the future interactions between the claimants on the East China Sea issues. The Tsai administration therefore must be careful of such chain effects transmitting between the two seas. But how to address maritime issues without deteriorating cross-strait relations will be a formidable task for the Tsai government.

Apart from the regional security issues, Taiwan is also in risk of being marginalized in the Asia-Pacific regional integration process. According to the number of FTAs, the Figure 2 shows that Singapore is the most active country participating in the regional integration in East Asia with 23 FTAs signed, 10 in negotiation, and 7 in plan. As of 2014, each East Asian states on average has seven FTAs signed, six in negotiation, and eleven in plan, while Taiwan currently has only two FTAs in negotiation and four in plan, far less than regional average, even though seven FTAs signed. Compared with South Korea, a major competitor to Taiwan in the international economic market, the number of South Korea's FTAs is two folds of Taiwan's. The empirical data here shows that Taiwan is in difficulties of signing FTAs.

${ }^{12}$ For the content of SCSPI, please see The R.O.C. Ministry of Foreign Affairs [2015]. 


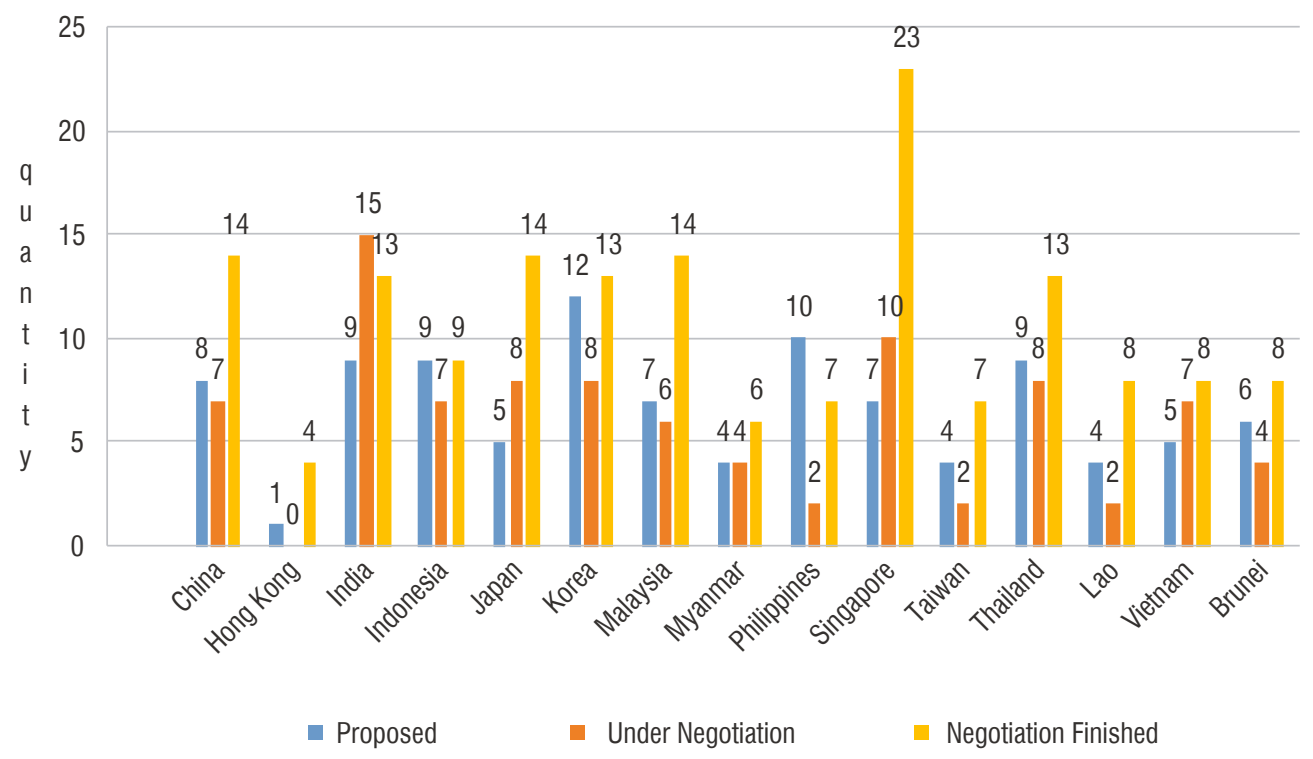

Figure 2. The Distribution of East Asian FTAs by Country (2014)

Source: Asian Regional Integration Center, Table 6. FTA Status by Country/Economy, 2014, Asian Development Bank, http://aric.adb.org/fta (28.01.2015).

Since Taiwan is an export-led economy, the formation of the TPP or the RCEP in the future will definitely affect Taiwan's competing position in the new wave of the Asia-Pacific regional integration. According to the statistics of Taiwan's Bureau of Foreign Trade, during the period of 2003-2013, the TPP member states in annual average accounted for about $32 \%$ of Taiwan's total exports and about $43 \%$ of total imports. Of the TPP member states, the United States, Japan, Singapore, Malaysia and Australia are major trade partners of Taiwan. In the same period, the RCEP member states in annual average accounted for Taiwan's exports and imports by $68 \%$ and 57\%, which indicates that Taiwan's trade relations with the RCEP member states are much closer than with the TPP member states. China (including Hong Kong and Macao), ASEAN (particularly Singapore, the Philippines, Vietnam, Thailand, and Malaysia) and Japan are top trade partners, together accounting for nearly a $60 \%$ of Taiwan's exports ${ }^{13}$. In other words, if Taiwan does not join the TPP and/or the RCEP, its industry sectors may be put in competitive disadvantage, even replaced by those in the TTP or the RCEP, due to suffering higher tariffs and non-tariff barriers in the regional market [ROC Ministry of Economic Affairs, 2015c, 2015d]. At the same time,

13 Trade statistics taken from "TPP introduction" compiled by ROC Ministry of Economic Affairs [2015a, 2015b]. 
without being in part of the TPP and the RCEP or having FTAs with the participants of these new regional trade agreements, Taiwan may also lose attractiveness to investments of foreign and local enterprises in the future, which can further worsen the development of industry sectors [Ye Changcheng, 2014, pp. 32-35; Shi Huici, Yan Huixin, Ye Changcheng, Hu Junan, 2014, pp. 145-184; Wu Yuying, 2014, pp. 24-28; Gu Yinghua, Lin Junfu, 2014, pp. 185-212; Legislative Yuan, Budget Center, 2014].

It is known in Taiwan that taking part in the RCEP and the TPP will help increase political and economic cooperation between Taiwan and the member states, explore new markets, and reduce economic dependence on China. However, China's attitude is the key of door for Taiwan to join the TPP and the RCEP. The TPP and the RCEP follow the rule of consensus decision for membership permission. Since China is the RCEP member state, Taiwan's participation clearly depends on China's decision. On the contrary, Taiwan's joining the TPP is much more promising in nearly future because the first round of the TPP negotiation has been completed and China is not a member state ${ }^{14}$. Although Taiwan has started consultation with the US about participating in the second round of the TTP negotiation [Trade Promotion..., 2015; Udn.com, 2015; CNA News, 2015] ${ }^{15}$, it may need to conclude the Trade and Investment Framework Agreement with the US in advance, which requests further market opening to the US. Meanwhile, even though China is not currently a member state of the TTP, it still can impede the TPP decision of membership offer to Taiwan via putting pressure on the US or other member states.

Since the factor of China makes it more difficult to Taiwan's participation in regional affairs, the Ma administration attempted to improve cross-strait relations through economic cooperation in order to mitigate such predicament. However, the Ma administration's cross-strait policy was called into questioned by Taiwan's society. The opponents stated that the $\mathrm{Ma}$ administration overestimated positive economic benefits of the ECFA and oversee possible negative impact on domestic economy. For example, China's generous economic offers may reduce incentives of reforming industrial structure and subsequently force Taiwan to more subject to China's market. As a result, Taiwan's international autonomy will be gradually eroded [Luo ZhiZheng, 2010, Wu Rongyi, 2010]. Some studies have pointed out that resulting benefit of the ECFA is not as much as expected [Gu Yinghua, Gao

${ }^{14}$ Although the Obama administration continues to push the US Congress to verify the TPP after the new "Trade Promotion Authority" Act passed, the time of TPP taking in force is uncertain because the presidential nominees of both the Republican and the Democrats is now in opposition to the TPP in the election campaign.

15 "Trade Promotion Authority" Act has been passed by the Senate. It is currently under examination by the House of Representatives [Trade Promotion..., 2015; Udn.com, 2015; CNA News, 2015]. 
Junyi, 2014, pp. 57-88; Tong Zhenyuan, 2014]. Besides, the opponents argued that people do not have throughout understanding of the impacts of the ECFA because of its opaque reviewing procedure. The ineffective communication between the $\mathrm{Ma}$ administration and domestic dissenters eventually led to the "Sunflower Movement" that took place on 18 March, 2014, resulting in suspension of proving the "Crossstrait Agreement on Trade in Services" signed in 2013 in Taiwan's Legislative Yuan. However, the emergence of the Sunflower Movement is not only showed a rejection to the Ma administration's cross-strait economic policy, but it also reveals the lack of consensus in Taiwan about further economic liberalization. In other words, Taiwan is not ready for tackling the comprehensive impacts of the TPP and the RCEP at the moment. In the Asia-Pacific region, Taiwan's FTA network is weak, with only FTAs with Singapore and New Zealand and the ECFA with China. This means that Taiwan relatively lacks stakes for bilateral as well as multilateral FTA negotiations, which consequently place greater difficulty in front of Taiwan on the way to the TPP and the RCEP. Moreover, although Taiwan currently starts to review and adjust economic institutions, the existing regulations are still far from matching the standards proposed by the TPP. Substantial adjustments of domestic legal and economic infrastructures for greater market liberalization will certainly generate impact on some of domestic industry sectors and their employment and inevitably give rise to social and political conflicts. These are the challenges standing in front of Taiwan's participation in the regional economic integration.

\section{Conclusion}

International security and the economic situation in the Asia-Pacific region is undergoing a structural change, but this change is a mix of security conflicts and economic integration and competition. From the viewpoint of regional security, though the related claimants call for peaceful settlement of the territorial disputes in the East China Sea and the South China Sea, but with China's growing strength and substance to assert territorial sovereignty, other related parties such as Japan, the Philippines, and Vietnam have actively counterbalanced China's actions in the two taters. This development also urged the United States to implement more explicitly the policy of rebalancing in Asia with increasing military activities in cooperation with the allies and related parties in East Asia to show its determination of returning to Asia. Although the risk of military conflict is increasing, the current status remains at the stage of fighting without splitting. However, the result of South China Sea Arbitration clearly shows international society that China's assertive actions in the 
South China Sea is without any legitimacy in terms of international law. Even though China publicly refutes the result, it is put in the relatively disadvantageous position in coping with the South China Sea issues in the multilateral as well as bilateral levels under more international pressures. The result of the arbitration in fact gives rise to a new condition of bargaining which may influence the existing international interactions in the region. Since Taiwan's territorial claim is also refuted by the result of the arbitration, Taiwan has to modify the current discourses and measures of protecting sovereignty to secure its national interest and prevent disadvantage that China now faces. In the tone of peaceful settlement of the disputes, Taiwan on the one hand must reinforce the legal argumentation on sovereignty claims and continues effective governing measures over its islands in the South China Sea. On the other hand, in addition to commonly developing and conserving marine resources, Taiwan can contribute more on non-traditional security, such as marine environmental protection, scientific studies, and humanitarian aid, which can help Taiwan to establish international reputation of good governance and peacemaker in the South China Sea. Though Taiwan and China are the only two countries simultaneously involving in the two troubled waters in the region, Taiwan is generally a passive actor. Nonetheless, increasing involvements of the United States, Japan, and regional countries engender a strategic opportunity for Taiwan to more actively participate in consultation, bargaining, and cooperation over the issues of the two waters. Against this strategic background, Taiwan has to grasp such chance to concretely demonstrate its stance and actively take advantage of transforming dynamics of interactions among the related parties so as to its critical role of regional security.

On regional economic integration, the establishment of the TPP and the RCEP not only reflects the member states' desires to advance national development but also shows their attempts to attain autonomy and advantage in the process of the Asia-Pacific regional economic integration. Although the TPP and the RCEP seem competing with each other, the overlap of their member states in fact renders possibility that the two integrating mechanisms may eventually converge toward a single free trade area. So, it is foreseeable that regional industry value chains will also undergo a sea change, and undoubtedly each regional country will seek for the best positions of the chains in order to avoid being marginalized and substituted in the integration process. However, Taiwan is relatively lagging behind with regard to the number of FTAs signed with regional countries, and it currently maintains its role in international trade and industry chains largely via APEC and WTO mechanisms and bilateral economic relations established in the past few decades. Participating the TPP and the RCEP which requests opening domestic market will unavoidably bring painful economic and societal frustrations. Nevertheless, it will compel industrial structure transition 
and manufacture technology upgrading, which will eventually carry out fruitful economic outcome. Although there have been many doubts about, even objections to, the ECFA in Taiwan, the implementation of the ECFA in appropriate way is still an important part in Taiwan's participation in new wave of the Asia-Pacific regional integration. Before joining in the TPP and the RCEP, besides continuing to reinforce bilateral investment and trade with the member states of the two integration system, it is also very important for Taiwan to power up its industrial innovation and improve conditions of domestic employment and investment market in order to maintain advantage in the changing economic landscape. Thus, Taiwan now is facing a critical moment in changing regional security and economic environment.

\section{Bibliographic References}

\section{Periodical}

Lin, Cheng-Yi [2016], Obama's South China Sea Policy: China's Response and Implications for Taiwan, “Soochow Journal of Politial Science”, no. 34(1) (林正義 [2016], 〈區巴馬政府 的南海政策：中國的回應及對台灣的影響〉。《東吳政治學報》 34,1 : 1-80).

Lin Zhengyi, Chen Hongjun [2014], Oil and Gas Exploration of Two "China" in the East China Sea and the Role of the United States and Japan, "Prospect Foundation Quarterly", no. 15(4).

Wu Yuying [2014], The Latest Progress in the Negotiations of Regional Comprehensive Economic Partnership Agreement (RCEP) and Its Impact on Taiwan's Economy and Coping, "Economic Prospects", no. 154.

Ye Changcheng [2014], Progress in the Negotiations of "Trans-Pacific Partnership" (TPP), its Possible Impact on Taiwan's External Political and Economic Relations and Coping, Economic Prospects (154).

\section{Book chapters}

Cai Zengjia [2012], The Development and Evolvment of the East China Sea Policy after Democratic Party of Japan's Coming to Power, in: East China Sea and South China Sea's disputes and peace prospects, He Sishen, Wang Guanxiong (ed.), "Cross-strait Exchanges Prospect Foundation", Taipei.

Gu Yinghua, Gao Junyi [2014], Overall Review and Early Harvest Benefit Assessment of ECFA, in: From ECFA to TPP: Taiwan's Road of Regional Economic Integration, "Cross-strait Exchanges Prospect Foundation", Taipei.

Gu Yinghua, Lin Junfu [2014], The Opportunites and Challenges RCEP Brings for Taiwan, in: From ECFA to TPP: Taiwan's Road of Regional Economic Integration, "Cross-strait Exchanges Prospect Foundation", Taipei. 
Li Qiongli [2012], ASEAN's Response and Influence to the Situation in the South China Sea, in: East China Sea and South China Sea's Disputes and Peace Prospects, He Sishen, Wang Guanxiong (ed.), "Cross-strait Exchanges Prospect Foundation”, Taipei.

Lin Zhengyi [2012], China's South China Sea Policy, in: East China Sea and South China Sea's Disputes and Peace Prospects, He Sishen, Wang Guanxiong (ed.), "Cross-strait Exchanges Prospect Foundation", Taipei.

Shi Huici, Yan Huixin, Ye Changcheng, Hu Junan [2014], Is Taiwan Ready to Join TPP?, in: From ECFA to TPP: Taiwan's Road of Regional Economic Integration, "Cross-strait Exchanges Prospect Foundation", Taipei.

Wang Gaocheng [2012], China's East China Sea Policy, in: East China Sea and South China Sea's Disputes and Peace Prospects, He Sishen and Wang Guanxiong (ed.), "Cross-strait Exchanges Prospect Foundation", Taipei.

Wang Guanxiong [2012], Conclusion: Searching for Peaceful Settlement of the East Asian Waters Disputes, in: East China Sea and South China Sea's Disputes and Peace Prospects, He Sishen, Wang Guanxiong (ed.), "Cross-strait Exchanges Prospect Foundation”, Taipei.

\section{Books}

Luo ZhiZheng (ed.) [2010], ECFA big Impact: Taiwan's Crises and Challenges, New Taiwan's think tank, Taipei.

Tong Zhenyuan [2014], Taiwan Economic Key Next Step - Cross-Strait Economic Integration Trends and Challenges, Boshuo, Taiwan.

Wu Rongyi (ed.) [2010], Deconstruction of ECFA: Taiwan's Fate and Chance, New Taiwan think tank, Taipei.

\section{Research report}

Legislative Yuan, Budget Center [2014], Impact of TPP and RCEP Regional Integration on Our Nation's Overall Economy (103139), Legislative Yuan, Taipei.

\section{Official documents}

APEC, 『Statement on the 25th Anniversary of APEC - Shaping the Future through AsiaPacific Partnership』 [2014] , http://www.apec.org/Meeting-Papers/Leaders-Declarations/2014/2014_aelm/2014_aelm_25th.aspx (7.01.2015).

The R.O.C. Ministry of Foreign Affairs [2012], The R.O.C. Government Propose 'The East China Sea Peace Initiative', 15 August 2012), http://www.mofa.gov.tw/News_Content.aspx?n=9FB 1B5F1C76243EE\&sms=20EB7F887746D351\&s=B3F2CDD313292AC0 (12.10.2014) (中華 民國外交部 [2012], 〈中華民國政府提出「東海和平倡議」〉 (2012/08/15), http://www. mofa.gov.tw/News_Content.aspx?n=9FB1B5F1C76243EE\&sms=20EB7F887746D351\&s= B3F2CDD313292AC0。2014/10/12). 
The R.O.C. Ministry of Foreign Affairs [2015], The South China Sea Peace Initiative, 26 May 2015, http://www.mofa.gov.tw/News_Content.aspx? $n=604$ CBAA3DB3DDA11\&sms $=69594088$ D2AB9C50\&s=3BEC439D5F6A9CEE (18.04.2016) (中華民國外交部 [2015]，〈南海和 平倡議〉 (2015/05/26), http://www.mofa.gov.tw/News_Content.aspx?n=604CBAA3DB 3DDA11\&sms=69594088D2AB9C50\&s=3BEC439D5F6A9CEE $\circ 2016 / 04 / 18$ ).

\section{News media}

American Defense Minister's Visit to Vietnam to Strengthen Defense Cooperation, Central News Agency [1.06.2015], http://www.cna.com.tw/news/aopl/201506010072-1.aspx (1.06.2015).

BBC Zhongwen [2014], Philipines Officially Issues an Arbitration Application on Disputes in South China Sea, 30 March 2014, http://www.bbc.com/zhongwen/trad/world/2012/09/120912_philippines_china_maritime (10.02.2015) (BBC中文網 [2014], 〈菲律賓正式將中菲南海爭議提 交國際仲裁〉。2014/03/30。http://www.bbc.com/zhongwen/trad/china/2014/03/140330_ china_philippines_dispute $\circ 2015 / 02 / 10)$.

BBC Zhongwen [2015], China's Military Fighter Jets Fly Near Japan, 28 November 2015, http://www. bbc.com/zhongwen/trad/world/2015/11/151128_china_military_jets_japan (18.04.2016) (BBC中文網 [2015], 〈中國多型戰機飛臨日本島嶼巡航〉。2015/11/28。http://www. bbc.com/zhongwen/trad/world/2015/11/151128_china_military_jets_japan 。2016/04/18).

BBC Zhongwen [2016], China: We have the Right to Build up Essential Defense Facilities on Chinese Territories, 17 February 2016, http://www.bbc.com/zhongwen/trad/china/2016/02/160217_ south_china_sea_chinese_missiles_paracels (18.04.2016) (BBC中文網 [2016]，〈中 國：「有權在本國領土上部署必要防禦設施」〉。2016/02/17。http://www.bbc. com/zhongwen/trad/china/2016/02/160217_south_china_sea_chinese_missiles_paracels $\circ 2016 / 04 / 18)$.

British Media: America Bombers Challenge China's No-fly-zone, BBC Chinese net [27.11.2013], http:// www.bbc.co.uk/zhongwen/trad/china/2013/11/131127_press_uk_uschinajapan (14.02.2015).

China Claimed that US Aircraft Reconnaissance Operations in the South China Sea "is Very Dangerous, BBC Chinese net [22.05.2015], http://www.bbc.co.uk/zhongwen/trad/china/2015/05/ 150522_china_us_south_sea (22.05.2015).

China Pushes "One Belt One Road" Strategy to Buils the Maritime Silk Road Bank, BBC Chinese net [13.11.2014], http://www.bbc.co.uk/zhongwen/trad/business/2014/11/141113_china_ new_silkroad_bank (7.01.2015).

China Sent Boats to Patrol the Fishing Island, and the Deadlock for 1,5 h with Japan, Apple Daily [21.11.2010], http://www.appledaily.com.tw/appledaily/article/international/20101121/ 32977741/ (7.01.2015).

China's Sending Fishery Patrol Boat to Paracel Islands", BBC Chinese net [15.03.2009], http://news. bbc.co.uk/chinese/trad/hi/newsid_7940000/newsid_7944500/7944504.stm (10.02.2015).

CNA News [2013], Philippines Apply an International Arbitration on Disputes in South China Sea, http://www.cna.com.tw/news/firstnews/201301220050-1.aspx (10.02.2015) (中央通 訊社 [2013], 〈南海爭議 菲律賓提國際仲裁〉。2013/01/22。http://www.cna.com. tw/news/firstnews/201301220050-1.aspx。2015/02/10). 
CNA News [2015], U.S. Assistant Secretary of State for East Asian and Pacific Affairs: U.S. and Taiwan Keep Striving on the Trading Issues, 15 May 2015, http://www.cna.com. tw/news/aopl/201505150024-1.aspx (20.05.2015) (中央通訊社 [2015], 〈美亞太助卿：美 台持續經貿努力〉。2015/05/15。http://www.cna.com.tw/news/aopl/201505150024-1. aspx $\circ 2015 / 05 / 20)$.

CNA News [2016a], President Ma Yin-Jeou Visit Taiping Island and Propose the South China Sea Peace Initiative, 28 January 2016, http://www.cna.com.tw/news/aipl/201601280165-1. aspx (18.04.2016) (中央通訊社 [2016a], 〈總統登太平島 提南海和平倡議路徑圖〉

-2016/01/28 • http://www.cna.com.tw/news/aipl/201601280165-1.aspx • 2016/04/18).

CNA News [2016b], Chinese Military Plane Lands Fiery Cross Reef, 18 April 2016, http://www. cna.com.tw/news/firstnews/201604180316-1.aspx (25.04.2016) (中央通訊社 [2016b], 〈中 共軍機首次公開降落永暑礁〉。2016/04/18。http://www.cna.com.tw/news/firstnews/ 201604180316-1.aspx。2016/04/25).

Diaoyutai Collision, Mutual Protest between China and Japan, from BBC, Chinese net [7.09.2010], http://www.bbc.co.uk/zhongwen/trad/china/2010/09/100907_china_japan_diaoyu_crash. $\operatorname{shtml}(7.01 .2015)$.

Hardy, J. O'Connor S. [2014], 『China building airstrip-capable island on Fiery Cross Reef』 , IHS Jane's Defence Weekly, http://www.janes.com/article/46083/china-building-airstrip-capableisland-on-fiery-cross-reef (7.01.2015).

James' Defense: Building Helipad in Nanji Island" Central News Agency [24.01.2015], http:// www.cna.com.tw/news/acn/201501240292-1.aspx (7.03.2015).

Kerry: The East China Sea peace Initiative has a Great Concern with the Asian Waters, Central News Agency [28.04.2015], http://www.cna.com.tw/news/aopl/201504280078-1. aspx (28.04.2015).

NIKKEI Zhongwen [2015], Japan Publicize the Pictures of China's Development of Oil and Gas Field on East China Sea, 22 July 2015, http://zh.cn.nikkei.com/politicsaeconomy/politicsasociety/15354-20150722.html (18.04.2016) (日經中文網 [2015], 〈日本公開中國開發 東海氣田證據照片〉。2015/07/22。http://zh.cn.nikkei.com/politicsaeconomy/politicsasociety/15354-20150722.html。2016/04/18).

On Check and Balance of the Forces in the South China Sea, Japan Joined the US-Australia Military Exercise, Central news Agency [26.05.2015], http://www.cna.com.tw/news/aopl/ 201505260016-1.aspx (27.05.2015).

ROC Ministry of Economic Affairs [2015a], Bureau of Foreign Trade, http://www.trade.gov. tw/App_Ashx/File.ashx?FilePath=../Files/Doc/ee07f984-6696-48a8-b102-e009ec8f66cb. $\operatorname{pdf}(6.03 .2015)$.

ROC Ministry of Economic Affairs [2015b], RCEP Introduction, http://www.trade.gov.tw/ App_Ashx/File.ashx?FilePath=../Files/Doc/01fc257b-b7b4-42a1-a954-c22a61df772b. pdf (6.03.2015).

ROC Ministry of Economic Affairs [2015c], Bureau of Foreign Trade, "The strategy to push our country to join TPP”, http://www.trade.gov.tw/App_Ashx/File.ashx?FilePath=../ Files/PageFile/40edf1ef-a4d6-4490-b613-d6432ca61c22.pdf (6.03.2015). 
ROC Ministry of Economic Affairs [2015d], Bureau of Foreign Trade, "The strategy to push our country to join RECP”, http://www.trade.gov.tw/App_Ashx/File.ashx?FilePath=../ Files/PageFile/40edf1ef-a4d6-4490-b613-d6432ca61c22.pdf (6.03.2015).

Secretary Panetta delivered remarks to the Engineering Academy of Armored Forces in Beijing, China [2012], September 12, http://www.defense.gov/transcripts/transcript.aspx?transcriptid $=5117(14.02 .2015)$.

The Attendance of President Today Morning in the Opening Ceremony of the '2015 World Association of International Law and the American Society of International Law Research Forum', the ROC Presidential Office press release (26.05.2015), http://www.president.gov. tw/Default.aspx?tabid=131\&itemid=34788\&rmid=514 (26.05.2015).

The Philippines Named Some Part of the South China Sea as the East Philippines Sea, BBC Chinese net [12.09.2012], http://news.bbc.co.uk/chinese/trad/hi/newsid_7940000/newsid_7944500/7944504.stm (10.02.2015).

The United States Appreciated President Ma's South China Sea Peace Initiative, Foreign Ministry Welcomed, Central News Agency (27.05.2015), http://www.cna.com.tw/news/aipl/ 201505270247-1.aspx (27.05.2015).

The US Assistant Secretary of State: The US and Taiwan Sustained Economic and Trade Efforts, Central News Agency (15.05.2015), http://www.cna.com.tw/news/aopl/201505150024-1. aspx (15.05.2015).

The US Military Urged China to Stop Sea Reclamation in the Spratly Islands Sea Area, Voice of America (23.11.2014), http://www.voacantonese.com/content/dhh-hk-us-calls-for-chinato-stop-reclamation-project-in-scs/2531110.html (8.01.2015).

The US Secretary of State Hillary Clinton stated such policy stand in Hanoi in 2010 [2010], Remark by Secretary Clinton at the Press on July 23, 2010, http://www.state.gov/secretary/ 20092013clinton/rm/2010/07/145095.htm (14.02.2015).

Trade Promotion Authority Act, Passed in Senate, Central News Agency [23.05.2015], http:// www.cna.com.tw/news/aopl/201505230067-1.aspx (24.05.2015).

Udn.com [2015], John Kerry: the U.S. and Taiwan Discussed the Second Round of TPP, 09 May 2015, http://udn.com/news/story/6656/891223-\%E6\%9F\%AF\%E7\%91\%9E\%EF\%BC\%9A\% E7\%BE\%8E\%E8\%88\%87\%E5\%8F\%B0\%E8\%AB\%AE\%E5\%95\%86TPP\%E7\%AC\%AC2\%E8 \%BC\%AA\%E8\%AB\%87\%E5\%88\%A4 (10.05.2015) (聯合新聞網 [2015], 〈凱瑞：美與台 諮商TPP第2輪談判〉。2015/05/09。http://udn.com/news/story/6656/891223-\%E6\%9F \%AF\%E7\%91\%9E\%EF\%BC\%9A\%E7\%BE\%8E\%E8\%88\%87\%E5\%8F\%B0\%E8\%AB\%AE\% Е5\%95\%86TPP\%Е7\%AC\%AC2\%E8\%BC\%AA\%E8\%AB\%87\%E5\%88\%A4 。 2015/05/10).

Vietnam Protested Again Against China's Damaging Vietnamese Survey Vessel, BBC Chinese net [9.06.2011], http://www.bbc.co.uk/zhongwen/trad/rolling_news/2011/06/110609_china_ vietnam 2011-05-31/ (10.02.2015). 
